\title{
Editorial
}

\section{Reflections on the year gone and the year to come}

\author{
International Journal of Disclosure and Governance (2008) 5, 285-286. doi:10.1057/jdg.2008.21
}

Looking back on the last year, I hope that readers will agree that it has been a time of great success for the journal. I hope that you enjoyed the previous issue that was the first to be entirely devoted to one topic: governance and disclosure in India. The stature of the authors of that issue is testament to the growing international credibility of the journal as the premier outlet for thought leaders in practice as well as in academia on governance and reporting issues.

Having examined the giant emerging market of India, it is only natural that the journal now turns its focus to the biggest nation of them all, the People's Republic of China. As the announcement in this issue and on the journal website indicates, the journal is about to undertake the single most important and ambitious development in its history: a conference to be held at the National Accounting Institute in Beijing examining governance, business ethics and reporting in China. Not only is this the first journal conference to be held outside the United States but also it will bring together an unprecedented number of participants and audience members from around the world. I hope that our readers from East Asia will take this opportunity to take part in the conference and to play a role in the continuing expansion of their journal into new markets and subject areas.

Remarkably, the Beijing conference will be the third journal conference in less than 18 months and there are already calls from interested parties wanting to host future journal conferences in Israel, North Africa and India. That demand is only a reflection of the under- lying hunger around the world for business systems that are more transparent, free and reliable, and it is that desire which forms the rationale for our journal.

This particular issue is largely based on the proceedings of the second journal conference, which was held at Rutgers Business School in Newark, New Jersey in May 2008. The focus of the conference was the subprime mortgage crisis and its implications for accounting, and the selection of papers and keynotes included here is only a partial reflection of the engrossing and sometimes heated discussions that took place in the conference. Two of the papers in this special issue, those by King and by Krumwiede, came from the panel discussion that was held on fair value accounting, which some have held as the villain in the credit crisis. Readers will have to make up their own minds on this contentious topic, but the very differing views of these two authors certainly make a strong case for each point of view. Of course, the fact that there can be such widely varying opinions about something as fundamental to accounting as the value of assets is perhaps the most important takeaway, that relevance and reliability in accounting remains as elusive goal as ever, and perhaps always will be.

The keynote address in the second journal conference was graciously made by $\mathrm{Mr}$ Simon Lorne, currently Vice Chairman and Chief Legal Officer of Millennium Management LLC, a New York-based hedge fund manager and formerly the General Counsel of the United States Securities \& Exchange Commission. $\mathrm{Mr}$ Lorne provided something that we don't perhaps focus enough on, caught up as we often 
are in the day-to-day crises of business: a big picture overview of the broad sweep of American capitalism and the debt it owes to the genius of Adam Smith's conception of free markets.

But his speech is more than a celebration; it is also a clear-eyed look at the limitations of the 'invisible hand' in today's globalised world. For example, while businesses extol the free market, the internal organisation of firms is more akin to authoritarian command and control than to laissez faire. It is worth recalling that the largest of businesses in Adam Smith's day would barely qualify as an SME today. From the divorce of management from ownership, to the ability of giant firms to distort markets and to control regulators, the underlying assumptions of Smith's conception of private enterprise are being increasingly questioned in a world dominated by multinationals, not to mention, as Lorne points out, of multi-trillion dollar sovereign wealth funds that were entirely unknown to Adam Smith.

Indeed, the key driver of a well-functioning free market is the self-interest of market participants which makes greed a source of social good rather than a personal failing, what Lorne calls 'the co-incidence of decision responsibility with decision consequence'. But whether that remains the case is the issue, both because of the sovereign wealth funds that can at any time put political goals ahead of economic ones and because of what Lorne believes is a fetish for independence. As he says, 'Today, in grasping for independence as the remedy for every ailment, we threaten to abandon that fundamental attribute of a market economy. An example:The Sarbanes-Oxley Act of 2002 effectively mandates majority-independent Boards of Directors and completely independent Board audit committees for publicly held companies. Now, if the function of a Board is more like that of the independent auditors - what I'll call true oversight - that may make some sense. If the function of the Board is decision making on behalf of the enterprise, however - and we ourselves at the same time are increasingly forcing Boards to be active decision makers - then independence is simply, and demonstrably, the wrong approach'.

Highlighting this quote is not to endorse it, but to illustrate the kinds of insights that arise from a setting as dynamic as the journal conference - insights that can then be elaborated on at leisure in a traditional journal article. Combining these approaches with the understanding that not all ideas important to business come from academia (to say the least, the unkind might say...) is what drives the approach adopted by this journal to judge the innovation and not the author, the impact and not the medium. I trust that the readers of this journal will support this more eclectic and less traditional approach towards journal content. I do hasten to add though, that this paper continues to seek deep and thoroughly researched papers that study and enhance corporate transparency and I am gratified that there was a record number of submissions to the journal over the last year.

Looking forward to 2009, I assure you that your journal will continue its growth and its search for the best and more informative insights into business. As the credit crisis, the takeover of mortgage firms, international crises such as that in Georgia, ever-rising energy, resource and agricultural prices, and a change in the US administration promise a difficult business climate in the year ahead, so the need for better disclosure and governance becomes ever more urgent.

Michael Alles

Editor 